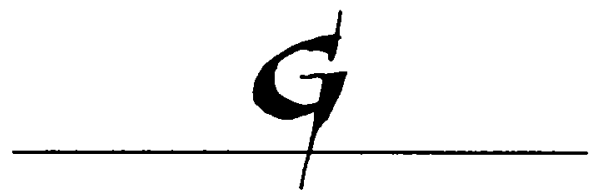

THE GEORGE GUND FOUNDATION IMPRINT IN APRICAN AMERICAN STUDIES

The George Gund Foundation has endowed this imprint to advance understanding of the history, culture, and current issues of African Americans. 
The publisher gratefully acknowledges the generous support of the African American Studies Endowment Fund of the University of California Press Foundation, which was established by a major gift from the George Gund Foundation. 
Negro Building 



\section{Negro Building}

Black Americans in the World of Fairs and Museums

\section{Mabel O. Wilson}

\section{甲ㅜ}

UNIVERSITY OF CALIFORNIA PRESS

Berkeley - Los Angeles · London 
University of California Press, one of the most distinguished university presses in the United States, enriches lives around the world by advancing scholarship in the humanities, social sciences, and natural sciences. Its activities are supported by the UC Press Foundation and by philanthropic contributions from individuals and institutions. For more information, visit www.ucpress.edu.

University of California Press

Berkeley and Los Angeles, California

University of California Press, Ltd.

London, England

Q 2012 by The Regents of the University of California

Library of Congress Cataloging-in-Publication Data

Wilson, Mabel (Mabel O.).

Negro building : Black Americans in the world of fairs and museums / Mabel $O$. Wilson.

p. $\mathrm{cm}$.

Includes bibliographical references and index.

IS BN 978-0-520-26842-5 (cloth : alk. paper)

I. African Americans-Exhibitions-History.

2. African Americans-Museums-History.

3. Exhibitions-Social aspects-United States-History.

4. Museums-Social aspects-United States-History.

5. Memory-Sucial aspects-United States-History.

6. Public history-United States-History. 7. SlavesEmancipation-United States. 8. African AmericansCivil rights-History. 9. Anti-racism-United StatesHistory. Io. United States-Race relations-History.

I. Title.

EI85.53.AIW55 2012

$305.896^{\prime} 073-\mathrm{dc} 23$

2011046242

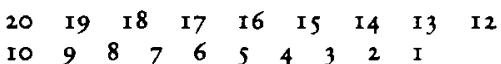


For my parents, Frank W. Wilson Jr.

and Ivery Outterbridge Wilson 
